This is a final peer-reviewed accepted manuscript. The final version has been published in Am J Enol Vitic. April 2016 67: 206-211, and it is available online at: https://doi.org/10.5344/ajev.2016.15058.

Research Article

\title{
Postveraison Shoot Trimming Reduces Cluster Compactness without Compromising Fruit Quality Attributes in Organically-Grown Sangiovese Grapevines
}

\author{
Bhaskar Bondada, ${ }^{1,5 *}$ José Ignacio Covarrubias, ${ }^{2}$ Paola Tessarin, ${ }^{1}$ \\ Aparecida Conceiçao Boliani, ${ }^{3}$ Gilmar Marodin, ${ }^{4}$ and Adamo Domenico Rombolà ${ }^{1}$ \\ ${ }^{1}$ Department of Agricultural Sciences, School of Agriculture and Veterinary Medicine, University of \\ Bologna, 40127 Bologna, Italy; ${ }^{2}$ Facultad de Ciencias Agronómicas, Universidad de Chile, Av. Santa \\ Rosa 11315, Santiago, Chile; ${ }^{3}$ Department of Phytotecnic, Food Sciences and Socio-Economy, Faculty of \\ Agricultural Engineering, State, University Paulista, CEP: 15385-000, Ilha Solteira, São Paulo, Brasil; \\ ${ }^{4}$ Departamento de Horticultura e Silvicultura, Faculdade de Agronomia, Universidade Federal do Rio \\ Grande do Sul, Porto Alegre, Brasil; and ${ }^{5}$ current address: Washington State University Tri-Cities, \\ Department of Horticulture, 2710 Crimson Way, Richland, WA 99354. \\ *Corresponding author (bbondada@wsu.edu; adamo.rombola@unibo.it) \\ Acknowledgment: Bhaskar Bondada is grateful to the University of Bologna, Bologna, Italy, for the \\ Senior Visiting Fellowship awarded through the Institute of Advanced Studies. \\ Manuscript submitted Jun 2015, revised Jul 2015, Jan 2016, accepted Jan 2016 \\ Copyright (c) 2016 by the American Society for Enology and Viticulture. All rights reserved.
}

Abstract: Vine performance following preveraison shoot trimming is well document, the consequences of such treatments later in the season are poorly understood. Therefore, a 4-yr study was conducted in a mature vineyard of Sangiovese (clone 12T) grafted onto Kober 5BB rootstock at a spacing of $1 \mathrm{~m} \mathrm{x} 2.8 \mathrm{~m}$ (intra- and interrow) to analyze the influence of postveraison shoot trimming on vine growth characteristics, cluster architecture (cluster compactness), and yield from a physiological viewpoint. The treatments consisted of shoot trimming during postveraison in a randomized block design with eight replications; each replication comprised of six vines. Three shoot trimming treatments consisting of light trimming (14 nodes), severe trimming (10 nodes), and an un-trimmed control were imposed when the soluble solids reached 15 Brix in August (40-45 day before expected harvest). Following the treatments, various vine growth characteristics, cluster morphology, and fruit quality attributes 
were measured. Postveraison shoot trimming, especially severe trimming reduced cluster weight along with cluster compactness, productivity, and total yield. In terms of fruit quality attributes, these reductions were manifested as lowering of Brix and $\mathrm{pH}$ with minor effects on TA, yeast assimilable nitrogen, the anthocyanin profile, and total anthocyanins. These results demonstrated that postveraison shoot trimming can be a valuable production practice in reducing cluster compactness without compromising overall fruit quality attributes in Sangiovese.

Key words: anthocyanin, Brix, growth, productivity, yield

\section{Introduction}

The cultivar Sangiovese is the most important Italian winegrape used for making prestigious Tuscan wines such as Brunello di Montalcino, Nobile di Montepulciano and Chianti. Although grown with both conventional and organic viticultural practices, organically-grown Sangiovese has been increasing for the last few years as organically generated products meet the standard requirements for quality as well as healthiness (Pagliarini et al. 2013). A key reproductive feature of Sangiovese is that regardless of how it is grown, it produces tight clusters, which are grouped as moderately compact, semi-compact, and compact (Nelson-Kluk 2006). Clusters of such morphology incur losses in cuticular barrier properties at the contact surfaces and hence become victims of a host of fungal diseases, mostly Botrytis cluster rot during ripening especially of grapevines grown with organic protocols. Other concerns include its tendency to overcrop ensuing from its high fruitfulness of shoots regardless of origin (primary or secondary buds, basal buds) and vigorous procumbent growth habit leading to dense canopies, which generally result in negative effects on fruit quality, wood maturity, and vine size maintenance (Poni et al. 2006). 
Combatting cluster rot has always been a multifaceted endeavor to have a profitable grape production. For instance, fungicides spray is one obvious option. However, it is an expensive short-term operation as pathogens develop resistance to fungicides overtime and thus it is unlikely that practical control of fungal diseases can be achieved by the use of fungicides alone. It is indeed true in organic viticulture necessitating an alternative and a more environmentally-benign approach as the chemicals that are organically certified add to more environmental problems rather than remedying the situation due to their ineffectiveness (Fragoulis et al. 2009). The other option is to employ various canopy management practices to improve the cluster architecture and subsequently microclimate by loosening the clusters, which minimizes fungal problems. For instance, defoliation decreased physical characteristics, number of berries, and cluster compactness in Trebbiano and Sangiovese (Poni et al. 2006). Other practices that reduced cluster compactness include cluster division (Molitor et al. 2012), type of irrigation method (drip irrigation versus partial rootzone drying), pruning strategy (spur pruning by hand, mechanical hedging or minimal pruning), and combination of irrigation and pruning that affected the number of clusters per vine and the rate of berry maturation (Leong et al. 2006). From a rootstock perspective, cluster compactness, berry skin strength, pedicel strength, and weights of cane and crop are greatly influenced by choice of cultivar (Ferreira and Marais, 1987). For instance, clusters of Chenin blanc on Jacquez were significantly less compact than those on Ramsey or 110 Richter (Ferreira and Marais, 1987).

Regardless of where it is practiced, the main thrust of organic farming including viticulture is to exploit ecologically balanced protocols deprived of chemical usage in order to avoid any environmental problem. Accordingly, organic grape growers resort to using mostly eco-friendly production practices with the exception that copper may be used only when there is 
an immediate risk of infection (Fragoulis et al. 2009). Furthermore, they treat the vineyard as an interactive ecosystem known as terroir in viticulture parlance entailing the regional physical (e.g. climate) and cultural domains (e.g. viticultural practices), which are put to best use towards optimizing yield and fruit quality. Because of the need to adhering to the principles of organic viticulture, organic grape growers seek out a wide repertoire of canopy management practices such as shoot topping (Molitor et al. 2015), shoot trimming (Martínez de Toda et al. 2013), pruning and leaf removal (Martin, 1990), hedging (Leong et al. 2006) etc. to maintain healthy vines. Of these, an ideal practice for improving the fruit and yield of organically-grown Sangiovese would be shoot trimming as it is easily mechanized and hence relatively simple to perform. It involves pruning at different locations along the shoot and is generally used to facilitate the movement of manpower and equipment between vineyard rows, to reduce vine vigor, avoid shade from overhanging shoots, and to facilitate harvest in grapevines with upright trellis system (e.g. VSP) in cool viticultural areas (Hatch et al., 2011). Since it is more of a facilitator of cultural operations, little information is available with respect to its impact on vine performance and fruit quality, especially when it is performed late in the season after veraison. Previous studies that dealt with shoot trimming were carried out during the early part of the season i.e. preveraison and examined reproductive growth, yield, ripening, and fruit and wine quality (Keller et al. 1999), all of which widely varied in their responses. Furthermore, none of these studies examined features such as growth characteristics of vine and cluster morphology, which have a strong bearing on the incidence of fungal diseases, especially in organic viticulture. This is the first study that demonstrates positive influence of postveraison shoot trimming in the form of reduced cluster compactness and fruit yield in Sangiovese grown with the norms of organic viticulture, which has been increasing for the last few years. 


\section{Materials and Methods}

Plant material and experimental layout. The experiment was conducted over four

102

103

104

105

106

107

108

109

110

111

112

113

114

115

116

117

118

119

120

121

years from 2008-2011 in a mature vineyard of Sangiovese (clone 12T) grafted onto Kober 5BB rootstock at a spacing of $1 \mathrm{~m} \mathrm{x} 2.8 \mathrm{~m}$ (intra- and interrow) for a density of 3571 vines/ha located

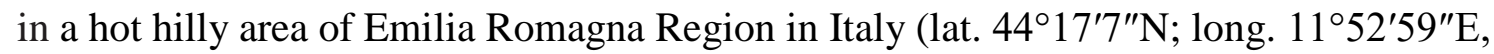
elevation $117 \mathrm{~m}$ asl). Since 2007, the vineyard established on diverse sub-soils of alluvial deposits has been managed with the principles of organic viticulture in accordance with Reg. EC 834/2007 (EC. 2007). Vines were trained to cordon de Royat training system consisting of a short trunk with a unilateral cordon trained to only one side of the trunk and hence extends from one vine to another. The vines were spur-pruned during winter to two count nodes equating to 12-14 nodes per vine. The noncount shoots (shoots arising from basal buds of the spur) were removed at the beginning and the cluster number was adjusted by cluster thinning. Throughout the experiment, the vines were maintained without any irrigation and fertilization.

The treatments consisted of shoot trimming during postveraison in a randomized block design with eight replications; each replication comprised of six vines (total of 144 vines). Prior to imposing the treatments, first vines were regularly (twice) trimmed to normalize a shoot length of $145 \mathrm{~cm}$ in each year. Thereafter, three shoot trimming treatments were imposed when the soluble solids reached 15 Brix in August (40-45 day before expected harvest). These include light trimming (LT of 14 nodes), severe trimming (ST of 10 nodes), and an un-trimmed control (CK 18 nodes). Shoot trimming was performed manually using large pruners. Following trimming, the shoot length in CK, LT and ST vines was 145, 102 and $64 \mathrm{~cm}$, respectively. The amount of leaf area removed following trimming treatments and maintained on vines were 

131 June.

measured in 2009 and 2010 growing seasons using a leaf-area meter (Li-CoR Biosciences, Lincoln, NE) by removing all leaves in single plants per replicate.

Climatic data. During each season, climatic data (mean, maximum and minimum daily air temperatures (T), relative humidity (RH) and total rainfall) were recorded from bud burst to harvest from a meteorological station located close to the vineyard.

2008. In 2008, from bud bust (March $26^{\text {th }}$ ) to harvest (September $24^{\text {th }}$ ), the growing season was characterized by average $\mathrm{T}$ of $19.4 \mathrm{C}$ with a maximum temperature of $34 \mathrm{C}$ occurring at the beginning of August. During the same period, the average RH varied from 45.5\% to 89.5\%. The total rainfall from bud burst to harvest $(243 \mathrm{~mm})$ occurred generally during April-

2009. In 2009, the average $T$ recorded from bud burst (April $3^{\text {rd }}$ ) to harvest, (September $23^{\text {rd }}$ ) was $22 \mathrm{C}$; maximum $\mathrm{T}$ of $38.7 \mathrm{C}$ occurred on July $23^{\text {rd }}$. The average RH varied from $43.1 \%$ to $100 \%$. The total rainfall from bud burst to harvest was $190 \mathrm{~mm}$ and predominantly took place in April and during the first week of July.

2010. In 2010, from bud burst to harvest (September $27^{\text {th }}$ ), the average daily $\mathrm{T}$ was $20 \mathrm{C}$ and the average RH varied from $39.3 \%$ to $92.8 \%$; there was an abundance of rainfall (464 mm), which occurred mostly in the spring and prior to harvest date.

2011. Overall, the 2011 growing season was marked by average $\mathrm{T}$ well above the seasonal normal with a maximum $\mathrm{T}$ of $30 \mathrm{C}$ occurring in the month of August. From bud burst to harvest (September $21^{\text {st }}$ ), the average RH varied from 40 to $70 \%$; highest values were observed during spring (92\%) and the lowest (38\%) during the latter part of August. The total rainfall from 
143 bud burst to harvest was $204 \mathrm{~mm}$, occurred generally during spring and almost none during 144 ripening.

145 Measurement of growth characteristics, yield, and yield components. Leaf area

146 maintained on vines and removed by trimming, were measured through leaf-area meter (Li-CoR

147 Biosciences, Lincoln, NE), by removing all leaves from one vine per replicate and leaves

148 belonging to a representative shoot in each vine. Cane length and pruning weight were

149 determined during winter. All prunings were weighed fresh. Yield and yield components (yield,

150 number of clusters, and cluster weight) were measured when berries met optimal universal set of

151 criteria (e.g. Brix, TA) to determine the same harvest date for all treatments. This was

152 determined by periodic sampling of berries starting in July. Accordingly, all treatments were

153 harvested when berries attained same maturity levels, i.e. when soluble solid concentration

154 reached a minimal value of 20 Brix, TA of less than 7.0 g/L etc., by taking into account the

155 qualitative (e.g. berry ripening disorders) and sanitary (e.g. cluster rot) status of the clusteres.

156 Cluster compactness was determined according to the 1983 OIV classification. Chlorophyll was

157 measured with a SPAD-502 chlorophyll meter (Minolta, Osaka, Japan).

158 Analysis of fruit composition. At harvest, berry weight, soluble solids (refractometer

159 PAL-1, ATAGO, Tokyo, Japan), titratable acidity (TA) and pH (Crison Compact Titrator, Crison

160 Instruments, Barcelona, Spain) were determined by randomly collecting 100 berries per

161 replication in each treatment. On the same samples, must YAN was determined by the method

162 described by Aerny (1996) and berry skin anthocyanins using HPLC methodology described by

163 Venencie et al. (1997). Briefly, for each sample, skins were peeled from 30 berries, weighed and

164 placed in $20 \mathrm{~mL}$ hydroalcoholic solution (EtOH:H2O, 10:90 v/v) containing $15 \mathrm{~mL}$ distilled

165 water and $2.5 \mathrm{~g}$ tartaric acid. The samples were homogenized with an Ultraturrax (IKA 
Labortechnik, Staufen, Germany) and centrifuged for 5 min at $3000 \mathrm{x} g$ at $20 \mathrm{C}$. The final

167 solution weight was adjusted to $100 \mathrm{~g}$ and $\mathrm{pH}$ to 3.6. The samples were then macerated for $24 \mathrm{hr}$

168 at $4 \mathrm{C}$ in dark and centrifuged (ALC International, PK121R, Italy) for $20 \mathrm{~min}$ at $1400 \mathrm{~g}$.

169 Thereafter, the samples were filtered under vacuum with Whatman Filter Paper 40, porosity 8

$170 \mu \mathrm{m}$. Skin anthocyanins were determined using a Waters 1525 instrument equipped with a diode

171 array detector (Waters Corporation, Milford, MA) and a reversed-phase column RP18 (Supelco

172 Inc., Bellefonte, PA); $5 \mu \mathrm{m}$ pore size; $250 \mathrm{~mm} \times 4 \mathrm{~mm}$. Signals were detected at $520 \mathrm{~nm}$. The

173 elution gradient consisted of the following solvents. Solvent A: water/formic acid (10\%, v/v)

174 (Romil Ltd., Cambridge, UK); solvent B: acetonitrile (Sigma-Aldrich, Milan, Italy). The binary

175 gradient applied was as follows: 0-7.9 min of 96\% A-4\% B; 7.9-23.0 min of 85\% A-15\% B;

$176 \quad 23.0-27.0$ min of $80 \%$ A-20\% B; 27.0-43.0 min of 70\% A-30 \% B; 43.1-45.0 96\%A-4\% B.

177 Anthocyanins were quantified by measuring peak area at $520 \mathrm{~nm}$. A calibration curve was

178 prepared from standard solutions of purified Oenin Chloride (Sigma-Aldrich, Milan, Italy) with

179 the concentrations between $50 \mathrm{mg} / \mathrm{L}$ and $500 \mathrm{mg} / \mathrm{L}$. The anthocyanins were expressed as mg/g of

180 berry skin. For each treatment, eight field replicates (each one deriving from a 6-plant

181 experimental plot) were measured. All field replicates were maintained separately and measured

182 in the laboratory. Therefore the number of field replicates equaled to analytical replicates.

183 Statistical analysis. Analysis of variance and comparison of means between treatments

184 were done by using SAS 6.04 software (SAS Institute, Cary, NC). Means were compared by the

185 Student-Newman-Keuls test $(P \leq 0.05)$. Cluster weight and cluster compactness were subjected 186 to Kruskall Wallis non-parametric test. 

treatments were imposed on the same vines each year with the consequence that the treatment effects accumulated throughout the experiments resulting alterations in growth and fruit quality attributes. For instance, the crop load (Ravaz index) increased with an increase in shoot trimming (Table 1), which needs to be interpreted with caution. This is because, the trimming treatments, while they altered the yield to pruning weight ratio, it was rather an imposed response, not a 195 developing response. On the other hand, berry weight declined with no differences among the 196 treatments during the first two years of experiment (2008-2009), remained the same in 2010, but

197 differed during the final year i.e. 2011 following the adoption of production practices of organic 198 viticulture in 2007 (Table 1). This indicated that reduction in berry weight following shoot trimming was a cumulative process, nevertheless the possible effects of smaller vine size and 200 relatively warmer season cannot be ignored. Cluster weight and yield per vine declined starting in 2008 (Table 1). The amount of leaf area removed and that remained on the vine following 202 shoot trimming showed differences among the three treatments (Table 1). Once again, such 203 whereas no difference was observed during the latter two years (2010-2011) (Table 3). No difference was observed in pH in 2008 and 2010 whereas the 2009 and 2011 seasons displayed 209 differences (Table 3). In contrast, the TA and YAN except for one year were immune to shoot 
210 trimming treatments (Tables 3). In a similar pattern, the anthocyanin profile (cyanidin, peonidin,

211 petunidin, delphinidin, malvidin) and total anthocyanins remained unaffected except for peonidin

212 and total anthocyanins in 2010, which tended to decline in response to shoot trimming

213 (Supplemental Table 1). Between the two shoot trimming treatments, the severe one in general

214 mostly induced differences (lowered the values) on the measured variables.

215

\section{Discussion}

Shoot trimming, the mainstay of this study, is one of the cultural repertoire of production practices to which grapevines adjust by forming tylose in the xylem vessels below the cut ends as a sealing mechanism to avoid water loss and pathogen entry into the vine (Sun et al. 2006). In the aftermath of shoot trimming following the sealed cut ends, the vine attains an altered state of shoot physiology and growth characteristics. This is particularly true when shoots are trimmed after veraison, the phenological event marking the inception of ripening (Poni and Intrieri, 1996). As a result, the effects of postveraison shoot trimming would be manifested in altered cluster and berry morphologies and eventually fruit composition. These are evident in our study wherein the postveraison shoot trimming reduced cluster compactness by loosening the clusters in Sangiovese, a cultivar well-known for its vigorous growth and large sized compact clusters of varying degree (moderately compact, semi-compact, and compact) (Nelson-Kluk 2006). A similar effect was observed when shoot topping (shoot tips tipped off $\sim 5 \mathrm{~cm}$ below the apex) was delayed until four weeks after the end of flowering in Riesling and Pinot gris (Molitor et al. 2015). Other canopy management practices that yielded similar effects include techniques of pruning and leaf removal (Martin 1990), but it was not clear as to what might have contributed to reducing cluster compactness and the consequent effects on fruit composition. As per this study, 
232 it was reduced berry size (weight) and cluster weight that loosened the clusters and the

233 ramification of this physiological activity in terms of productivity was reduced yield per vine,

234 which was expected as berry and cluster weights are a function of productivity. This trade-off is

235 a highly sought after feature by the practitioners of organic viticulture as loosened clusters by

236 virtue of increased epicuticular wax load and cuticle thickness become less susceptible to cluster

237 rots (Martin 1990). Accompanying the loosened clusters were low Brix, $\mathrm{pH}$, and yield. This is a

238 reflection of constrained ripening associated with reduced leaf area following shoot trimming

239 (Stoll et al. 2009). Contrary to our study, these attributes reacted far more negatively (i.e. drastic

240 reductions) when a similar form of severe shoot trimming was performed after fruit set (berry

241 diameter 3-4 $\mathrm{mm}$ ) by excising the internode just above the distal clusters of Grenache and

242 Tempranillo (Martínez de Toda et al. 2013). Then again, analogous treatments of our study

243 (trimming to the $10^{\text {th }}$ node) performed early in the season (pre-veraison) not only elongated

244 clusters but also increased yield and Brix (Cartechini et al. 2000) except for its combination with

245 nitrogen application, wherein shoot trimming decreased fruit quality (Keller et al. 1999). While

246 the Brix, pH, and yield were reduced, the anthocyanin profile and total anthocyanins remained

247 unaffected by shoot trimmings. Herrera et al. (2015) observed the same phenomenon when

248 Merlot vines were subjected to severe canopy reduction during early stages of ripening. These

249 studies confirm that many of the precursors for anthocyanin development accumulate pre-

250 veraison (Dokoozlian and Kliewer 1996) whereas the postveraison anthocyanin accumulation is

251 mediated by sugars inducing genes for encoding enzymes in the anthocyanin biosynthesis

252 pathway (Conde et al. 2007). If this is the case, then what was the source of sugars for

253 accumulating anthocyanins in trimmed shoots? The obvious one is the reserves, which are

254 stimulated to hydrolyze by pruning activities into sugars so as to remobilize them into the sink 
organs-in-need (Clair-Maczulajtys et al. 1996). Conversely, shoot-trimming during pre-veraison

256 (Cartechini et al. 2000) or when shoots were trimmed to two leaves per cluster reduced

257 polyphenols including anthocyanins due to inhibition of anthocyanin biosynthetic enzymes (Wu

258 et al. 2013). The same phenomenon is responsible for anthocyanin losses under conditions of

259 high temperature (Mori et al. 2007), which explains the lower anthocyanin levels in 2011, a

260 relatively much warmer season than the preceding wet seasons receiving high rainfall (190-455

$261 \mathrm{~mm}$ ) from budbreak to harvest. Such results are a testimony to climatic differences playing a

262 major role in inducing seasonal variations in growth and fruit quality attributes (Herrera et al.

263 2015). The TA analogous to anthocyanins was not affected either. Such a response was expected

264 of as grape berries complete acid accumulation by synthesizing most of it in situ not later than

265 veraison (Conde et al. 2007). In contrast, the accumulation of nitrogen in the form of $\alpha$-amino

266 acids and ammonia contributing to the pool of YAN increases at the onset of veraison (Bell and

267 Henschke 2008) and requires continuous supply of photoassimilates (Perez and Kliewer 1982).

268 Hence, not surprisingly, the YAN levels declined with the removal of leaves due to shoot

269 trimming.

270 Since the physiological status of vines at a given phenological event determines

271 morphological features and shapes fruit quality attributes, the next logical proceeding is to

272 analyze cluster architecture and fruit composition of trimmed shoots in the context of vine

273 physiology and growth characteristics to understand the mechanics behind observed changes. In

274 view of that, what ensued from postveraison shoot trimming was an unexpected and accelerated

275 senescence of the shoot system. When this happens, the source:sink ratio declines and

276 subsequently the overall photosynthetic capacity is compromised (Poni et al. 2003). This is

277 simply due to the fact that the most photosynthetically active leaves during ripening are located 
at the top of the canopy and those arising from lateral shoots (Candolfi-Vasconcelos et al. 1994). These sources provide abundant supply of assimilates for increasing both yield and Brix (Poni and Intrieri 1996), which did not occur in our study due to severe shoot trimming after veraison. On the other hand, if shoots are trimmed lightly (e.g. shoot topping) early in the season (before veraison), Brix and yield increase due to elimination of competing organs of shoot tip (Cartechini et al. 2000). Based on these observations, it is logical to infer that source limitation reduces Brix and yield. But then again, one may argue that shoot trimming should enhance ripening as it induces lateral growth with more photosynthetically efficient leaves for transporting assimilates into the berry (Koblet et al. 1996). The compensatory lateral growth for supporting berries did not surface in our study as shoots trimmed after veraison induce little regrowth (Poni and Intrieri 1996).

Other consequences of postveraison shoot trimming relates to an imbalanced (decreased) source:sink ratio resulting in a shift in sink strength, the ability to attract photosynthates towards stems and roots limiting partitioning into berries (Kriedemann and Lenz 1972). In this study, roots whose sink strength is generally weakened in the presence of fruits, the organs with the highest sink potential (Minchin and Lacointe 2005), became the next strongest sink as these are the site of cytokinin synthesis and any tissue or organ enriched with cytokinins is known to attract assimilates (Ronzhina 2004). Further support comes from Ravaz index (yield:pruning weight ratio), a measure of crop load and source-sink relationship (Kliewer and Dokoozlian 2005) increased with trimming treatments. However, such evidence needs to be interpreted with caution as the increase in Ravaz index primarily ensued from losses of leaves and stems caused by shoot trimming per se. Given the severity of the trimming, the loss in shoot dry matter in our study is estimated to be more than $25 \%$. As a result, most of the assimilates freed by fruits were 
mobilized into roots, a cogent course of action not only to avoid death of fine roots but also to replenish the sugars lost to bud break and early summer growth.

The reduced sink strength of berries in the shoot-trimmed clusters is also a reflection of resistance to flow in the phloem pathway (Minchin and Lacointe 2005) due to plugging of sieve plates of the phloem sieve tubes with callose, a polymer of carbohydrate, which is synthesized naturally when vines go into dormancy (Bondada, 2014). Its synthesis can also be induced by abiotic stress (Bondada 2014), hence, it is highly possible that the stress caused by trimming (Candolfi-Vasconcelos et al. 1994) might have accelerated an early synthesis of callose thereby reducing sugar export into the berries and the fact that postveraison berry expansion relies on phloem influx (Bondada et al. 2005), a resistant phloem will reduce berry size by reducing its sink strength. Although these premises lend credible physiological explanations for the lower Brix of shoot-trimmed clusters, they need to be evaluated in future studies.

\section{Conclusions}

Grapevines are subjected to many different cultural practices that may or may not favor fruit quality. The results of this study on shoot trimming are in favor of promoting positive effects on cluster morphology and fruit quality i.e. a reduction in cluster compactness and sugar levels, which ensued from source-sink imbalance associated with postveraison shoot trimming. Despite reductions in yield and sugar levels, the overall fruit quality was not lost to shoot trimming. This is a reflection of adaptive nature of grapevine conferring them with adjustments to maintain homeostasis. Grapes with reduced sugar levels is highly attractive to wineries as they can be fermented into balanced wines of reduced alcohol content with relative ease; such qualities are highly desired in today’s market and by consumers. From an environmental 
339

340

341

342

343

344

345

346

347

348

349

350

351

352

353

354

355

perspective, the cultural practice of shoot trimming is ideal to organic viticulture, which aims at promoting and enhancing biodiversity and soil biological activity. Hence, this practice is worthy of deserving recommendation to organic grape growers as an effective cultural practice for reducing sugar levels in tandem with cluster compactness in Sangiovese.

\section{Literature Cited}

Aerny, J. 1996. Composés azotés des moûts et vins. Rev. Suisse Vitic. Arboric. Hortic. 28:161165.

Bell, S.J., and P.A. Henschke. 2008. Implications of nitrogen nutrition for grapes, fermentation and wine. Aust. J. Grape Wine Res. 11:242-295.

Bondada, B.R., M.A. Matthews, and K. A. Shackel. 2005. Functional xylem in grapevine berries. J. Exp. Bot. 56:2949-2956.

Bondada, B. 2014. Structural and compositional characterization of suppression of uniform ripening in grapevine: A paradoxical ripening disorder of grape berries with no known causative clues. J. Am. Soc. Hort. Sci. 139:567-581.

Candolfi-Vasconcelos, M.C., M.P. Candolfi, and W. Koblet. 1994. Retranslocation of carbon reserves from the woody storage tissues into the fruit as a response to defoliation stress during the ripening period in Vitis vinifera L. Planta 192:567-573.

Cartechini, A., A. Palliotti, C. Lungarotti. 2000. Influence of timing of hedging on yield and grape quality in some red and white grapevine cultivars. Acta Hort. 512:101-110.

Clair-Maczulajtys, D., I. Le Disquet, and G. Bory. 1996. Pruning stress: changes in the tree physiology and their effects on the tree health. Acta Hort. 496:317-324.

Conde, C., P. Silva, N. Fontes, A.C.P. Dias, R.M. Tavares, M.J. Sousa, A. Agasse, S. Delrot, and H. Gerós. 2007. Biochemical changes throughout grape berry development and fruit and wine quality. Food 1:1-22.

Dokoozlian, N.K., and W.M. Kliewer. 1996. Influence of light on grape berry growth and composition varies during fruit development. J. Am. Soc. Hort. Sci. 121:869-874. 
356 Ferreira, J.H.S., and P.G. Marais. 1987. Effect of rootstock cultivar, pruning method and crop

357 load on Botrytis cinerea rot of Vitis vinifera cv. Chenin blanc grapes. S. Afr. J. Enol. Vitic. 8:4135844.

359

360

Fragoulis, G., M. Trevisan, A.D. Guardo, A. Sorce, M.V. Meer, F. Weibel, and E. Capr. 2009.

361 Development of a management tool to indicate the environmental impact of organic viticulture.

362 J. Environ. Qual. 38:826-835.

363

364

365

366

367

368

369

370

371

372

373

374

375

376

377

378

379

380

381

382

383

384

385

386

387

388

389

390

391

392

393

394

Hatch, T.A., C.C. Hickey, and T.K. Wolf. 2011. Cover crop, rootstock, and root restriction regulate vegetative growth of Cabernet Sauvignon in a humid environment. Am. J. Enol. Vitic. 62:298-311.

Herrera, J.C., B. Bucchetti, P. Sabbatini, P. Comuzzo, L. Zulin, and A. Vecchione. 2015. Effect of water deficit and severe shoot trimming on the composition of Vitis vinifera L. Merlot grapes and wines. Aust. J. Grape Wine Res. 21:254-265.

Keller, M., R. M. Pool, and T. Henick-Kling. 1999. Excessive nitrogen supply and shoot trimming can impair colour development in Pinot noir grapes and wine. Aust. J. Grape Wine Res. 5:45-55.

Kliewer, M., and N.K. Dokoozlian. 2005. Leaf area/crop weight ratios of grapevines: Influence on fruit composition and wine quality. Am. J. Enol. Vitic. 56:170-181.

Koblet, W., M.C. Candolfi-Vasconcelos, and M. Keller. 1996. Stress und Stressbewältigung bei Weinreben. Bot. Helv. 106:73-84.

Kriedemann, P.E., and F. Lenz. 1972. The response of vine leaf photosynthesis to shoot tip excision and stem cincturing. Vitis 11:193-197.

Leong, S.L., A.D. Hocking, J.I. Pitt, B.A. Kazi, R.W. Emmett, and E.S. Scott. 2006. Australian research on ochratoxigenic fungi and ochratoxin A. Int. J. Food Microbiol. 111:S10-S17.

Martin, S.R. 1990. Systematic management to minimize botrytis cluster rot in three victorian vineyards. Aust. New Zealand Wine Indust. J. 5:235-237.

Martínez de Toda, F., J.C. Sancha, and P. Balda. 2013. Reducing the sugar and pH of the grape (Vitis vinifera L. cvs. 'Grenache' and 'Tempranillo') through a single shoot trimming. S. Afr. J. Enol. Vitic. 34:246-251. 
424

425

426

427

428

429

430

431

Minchin, P.E.H., and A. Lacointe. 2005. New understanding on phloem physiology and possible consequences for modelling long-distance carbon transport. New Phytol. 166:771-779.

Molitor, D., M. Behr, L. Hoffmann, and D. Evers. 2012. Impact of grape cluster division on cluster morphology and cluster rot epidemic. Am. J. Enol. Vitic. 63:508-514. Molitor, D., N. Baron, T. Sauerwein, C.M. Andre, A. Kicherer, J. Doring, M. Stoll, M. Beyer, L. Hoffmann, and D. Evers. 2015. Postponing first shoot topping reduces grape cluster compactness and delays cluster rot epidemics. Am. J. Enol. Vitic. 66:164-176.

Mori, K., N. Goto-Yamamoto, M. Kitayama, M. and K. Hashizume. 2007. Loss of anthocyanins in red wine grape varieties under high temperature. J. Exp. Bot. 58:1935-1945.

Nelson-Kluk, S. 2006. Sangiovese at FPS. FPS Grape Program Newsletter, November, 2006.

OIV, 1983. Le code des caractères descriptifs des variétés et espèces de Vitis. Office International de la Vigne et du Vin, Ed. Dedon, Paris.

Pagliarini, E., M. Laureati, and D. Gaeta. 2013. Sensory descriptors, hedonic perception and consumer's attitudes to Sangiovese red wine deriving from organically and conventionally grown grapes. Front. Psychol. 4:1-7.

Perez, J.R., and W.M. Kliewer. 1982. Influence of light regime and nitrate fertilization on nitrate reductase activity and concentrations of nitrate and arginine in tissues of three cultivars of grapevines. Am. J. Enol. Vitic. 33:86-93.

Poni, S. and C. Intrieri. 1996. Physiology of grape leaf ageing as related to improved canopy management and grape quality. In Proceedings of the $9^{\text {th }}$ Australian Wine Industry Technical Conference. C.S. Stockley, A.N. Sas, R.S. Johnstone and T.H. Lee (eds). pp. 113-122. Adelaide, Australia (Winetitles).

Poni, S., M. Quartieri, and M. Tagliavini, 2003. Potassium nutrition of Cabernet Sauvignon grapevines (Vitis vinifera L.) as affected by shoot trimming. Plant Soil 253: 341-351.

Poni S., L. Casalini, F. Bernizzoni, S. Civardi, and C. Intrieri. 2006. Effects of early defoliation on shoot photosynthesis, yield components, and grape composition. Am. J. Enol. Vitic. 57:397407. 
432 Ronzhina, E.S. 2004. Structural and functional rearrangements of mesophyll as a probable basis

433 for the cytokinin-dependent assimilate translocation in detached leaves. Russian J. Plant Physiol.

434 51:333-341.

435

436 Stoll, M., M. Scheidweiler, M. Lafontaine, and H.R. Schultz. 2009. Possibilities to reduce the

437 velocity of berry maturation through various leaf area to fruit ratio modifications in Vitis vinifera

438 L. Riesling. In Proceedings of $16^{\text {th }}$ international GiESCO Symposium. N. Dokoozlian and J.

439 Wolpert (eds.). pp. 93-96. University of California, Davis, CA, USA.

440

441 Sun, Q., T.L. Rost, and M.A. Matthews. 2006. Pruning-induced tylose development in stems of 442 current-year shoots of Vitis vinifera (Vitaceae). Am. J. Bot. 93:1567-1576.

443

444 Venencie, C., M.N. Uveira, and S. Guiet. 1997. Maturité polyphénolique du raisin mise en place 445 d'une méthode d'analyse de routine. Rev. Fr. Oenol. 167:36-41.

446

447 Wu, B.H., N. Niu, J.H. Li, and S.H. Li. 2013. Leaf:fruit ratio affects the proteomic profile of 448 grape berry skins. J. Am. Soc. Hort. Sci. 138:416-427. 
Table 1 Growth characteristics, crop load, and yield and yield components in control, lightly and severely trimmed Sangiovese vines from 2008-2011.

\begin{tabular}{|c|c|c|c|c|c|c|c|c|}
\hline Year & Treatment & $\begin{array}{c}\text { Pruning } \\
\text { wt } \\
\text { (kg/vine) }\end{array}$ & $\begin{array}{l}\text { LA1 } \\
\left(m^{2}\right)\end{array}$ & $\begin{array}{l}\text { LA2 } \\
\left(\mathrm{m}^{2}\right)\end{array}$ & $\begin{array}{c}\text { Yield } \\
\text { (kg/plant) }\end{array}$ & $\begin{array}{c}\text { Ravaz } \\
\text { index }\end{array}$ & $\begin{array}{c}\text { Cluster } \\
\text { wt } \\
\text { (g) }\end{array}$ & $\begin{array}{c}\text { Berry } \\
\text { wt } \\
\text { (g) }\end{array}$ \\
\hline & CK & $0.47 \mathrm{a}$ & $4.5 \mathrm{a}$ & - & $5.6 \mathrm{a}$ & $11.9 \mathrm{~b}$ & $332.0 \mathrm{a}$ & 2.2 \\
\hline \multirow[t]{4}{*}{2008} & ST & $0.39 \mathrm{~b}$ & $2.9 \mathrm{~b}$ & 1.3 & $5.2 \mathrm{ab}$ & $13.3 \mathrm{~b}$ & $3.18 .4 \mathrm{ab}$ & 2.1 \\
\hline & $\mathrm{LT}$ & $0.25 \mathrm{c}$ & $2.4 \mathrm{c}$ & 2.5 & $4.7 \mathrm{~b}$ & $18.8 \mathrm{a}$ & 282.6 b & 2.0 \\
\hline & Significance & $* * *$ & $* *$ & $* * *$ & $*$ & $* * *$ & $*$ & ns \\
\hline & CK & $0.55 \mathrm{a}$ & $3.6 \mathrm{a}$ & - & $3.4 \mathrm{a}$ & $6.0 \mathrm{~b}$ & $268.1 \mathrm{a}$ & 2.6 \\
\hline \multirow[t]{4}{*}{2009} & ST & $0.42 \mathrm{~b}$ & $2.8 \mathrm{ab}$ & 1.1 & $3.2 \mathrm{ab}$ & $7.6 \mathrm{ab}$ & $245.9 \mathrm{ab}$ & 2.5 \\
\hline & $\mathrm{LT}$ & 0.29 c & $2.1 \mathrm{~b}$ & 1.6 & $2.6 \mathrm{~b}$ & 9.b & $210.2 \mathrm{~b}$ & 2.4 \\
\hline & Significance & $* * *$ & $* * *$ & ns & $*$ & $* *$ & * & ns \\
\hline & $\mathrm{CK}$ & $0.66 \mathrm{a}$ & $2.9 \mathrm{a}$ & - & $5.4 \mathrm{a}$ & $8.2 \mathrm{~b}$ & 294.5 a & 2.5 \\
\hline \multirow[t]{4}{*}{2010} & ST & 0.55 a & $2.4 \mathrm{~b}$ & 0.9 & $4.7 \mathrm{ab}$ & $8.5 \mathrm{~b}$ & $260.5 \mathrm{~b}$ & 2.5 \\
\hline & $\mathrm{LT}$ & $0.40 \mathrm{~b}$ & $1.3 \mathrm{c}$ & 0.6 & $4.0 \mathrm{~b}$ & $10.0 \mathrm{a}$ & $246.8 \mathrm{~b}$ & 2.5 \\
\hline & Significance & $* *$ & $* * *$ & $* * *$ & $*$ & $*$ & $*$ & ns \\
\hline & CK & $0.42 \mathrm{a}$ & $4.9 \mathrm{a}$ & - & $2.5 \mathrm{a}$ & $6.0 \mathrm{~b}$ & $216.1 \mathrm{a}$ & $2.1 \mathrm{a}$ \\
\hline \multirow[t]{3}{*}{2011} & ST & $0.32 \mathrm{~b}$ & $2.7 \mathrm{~b}$ & 0.8 & $2.2 \mathrm{a}$ & $6.9 \mathrm{ab}$ & $191.6 \mathrm{~b}$ & $1.9 \mathrm{~b}$ \\
\hline & $\mathrm{LT}$ & $0.21 \mathrm{c}$ & $1.9 \mathrm{c}$ & 1.2 & $1.8 \mathrm{~b}$ & $8.6 \mathrm{a}$ & $158.9 \mathrm{~b}$ & $1.8 \mathrm{~b}$ \\
\hline & Significance & $* * *$ & $* * *$ & $*$ & $* *$ & $*$ & $* *$ & $* * *$ \\
\hline
\end{tabular}

*Significant at $p<0.05,{ }^{* *}$ significant at $p<0.01$, *** significant at $p<0.001$, ns, not significant. Means within a column followed by different letters are significantly different according to the StudentNewman-Keuls test (pruning weight, Ravaz index, LA, berry weight, yield) and Kruskal-Wallis test (cluster weight). CK, control vines; LT, lightly trimmed vines; ST severely trimmed vines; LA1, leaf area before imposing the treatments; LA2, leaf area after imposing the treatments.

Table 2 Cluster compactness (OIV rating) in control, lightly and severely trimmed Sangiovese vines from 2010 and 2011 experiments.

\begin{tabular}{ccc}
\hline \multirow{2}{*}{ Treatment } & \multicolumn{2}{c}{ Cluster compactness } \\
\cline { 2 - 3 } & $\mathbf{2 0 1 0}$ & $\mathbf{2 0 1 1}$ \\
\hline CK & $6.5 \mathrm{a}$ & $7.3 \mathrm{a}$ \\
LT & $6.6 \mathrm{a}$ & $5.5 \mathrm{~b}$ \\
ST & $5.6 \mathrm{~b}$ & $5.6 \mathrm{~b}$ \\
Significance & $*$ & $*$ \\
\hline
\end{tabular}

\footnotetext{
*Significant at $p<0.05$. Means within a column followed by different letters are significantly different according to the Student- Newman-Keuls test. CK, control vines; LT, lightly trimmed vines; ST, severely trimmed vines.
} 
Table 3 Berry compositional attributes in control, lightly and severely trimmed Sangiovese vines from 2008-2011.

\begin{tabular}{|c|c|c|c|c|c|}
\hline Year & Treatment & $\begin{array}{l}\text { TSS } \\
\text { (Brix) }\end{array}$ & $\mathrm{pH}$ & $\begin{array}{c}\text { TA } \\
\text { (g/L tartaric } \\
\text { acid) }\end{array}$ & $\begin{array}{c}\text { YAN } \\
(\mathrm{mg} / \mathrm{L})\end{array}$ \\
\hline \multirow{4}{*}{2008} & $\mathrm{CK}$ & $22.7 \mathrm{a}$ & 3.30 & 6.8 & \\
\hline & $\mathrm{ST}$ & $21.5 \mathrm{ab}$ & 3.30 & 7.0 & \\
\hline & $\mathrm{LT}$ & $20.7 \mathrm{~b}$ & 3.20 & 7.1 & \\
\hline & Significance & $*$ & ns & ns & \\
\hline \multirow{4}{*}{2009} & $\mathrm{CK}$ & $24.2 \mathrm{a}$ & $3.40 \mathrm{a}$ & 4.6 & 165 a \\
\hline & $\mathrm{ST}$ & $23.4 \mathrm{~b}$ & $3.30 \mathrm{ab}$ & 4.4 & $142 \mathrm{~b}$ \\
\hline & $\mathrm{LT}$ & $23.5 \mathrm{~b}$ & $3.4 \mathrm{~b}$ & 4.9 & $140 \mathrm{~b}$ \\
\hline & Significance & $*$ & $* * *$ & ns & $*$ \\
\hline \multirow{4}{*}{2010} & $\mathrm{CK}$ & 20.9 & 3.11 & 7.0 & 106 \\
\hline & $\mathrm{ST}$ & 20.5 & 3.11 & 7.1 & 105 \\
\hline & $\mathrm{LT}$ & 20.6 & 3.13 & 6.7 & 116 \\
\hline & Significance & ns & ns & ns & ns \\
\hline \multirow{4}{*}{2011} & $\mathrm{CK}$ & 25.6 & 3.49 a & 7.0 & 99 \\
\hline & ST & 25.4 & $3.45 \mathrm{~b}$ & 6.9 & 91 \\
\hline & $\mathrm{LT}$ & 25.3 & $3.41 \mathrm{c}$ & 6.7 & 81 \\
\hline & Significance & ns & $* * *$ & ns & ns \\
\hline
\end{tabular}

*Significant at $p<0.05, * *$ significant at $p<0.01$, significant at $p<0.001$. Means within a column followed by different letters are significantly different according to the Student- Newman-Keuls test. CK, control vines; LT, lightly trimmed vines; ST, severely trimmed vines; TA, titratable acidity; TSS, total soluble solids; YAN, yeast assimilable nitrogen. 
Supplemental Table 1 Concentration (mg/g of skin) of individual anthocyanins at harvest in berries of control, lightly, and severely trimmed Sangiovese vines from 2008-2011. Cyanidin-3-glucoside (cn-3G); peonidin-3-glucoside (pn-3G); delphinidin-3-glucoside (dp-3G); petunidin-3-glucoside (pt-3G); malvidin3-glucoside (mv-3G); and total glycosylated anthocyanin (tot-G).

\begin{tabular}{|c|c|c|c|c|c|c|c|}
\hline Year & Treatment & cn-3G & pn-3G & dp-3G & pt-3G & mv-3G & tot-G \\
\hline \multirow{4}{*}{2008} & CK & 0.28 & 0.21 & 0.21 & 0.24 & 0.71 & 1.64 \\
\hline & $\mathrm{LT}$ & 0.26 & 0.19 & 0.21 & 0.24 & 0.71 & 1.61 \\
\hline & ST & 0.28 & 0.19 & 0.20 & 0.23 & 0.65 & 1.55 \\
\hline & Significance & n.s. & n.s. & n.s. & n.s. & n.s. & n.s. \\
\hline \multirow{4}{*}{2009} & CK & 0.34 & 0.21 & 0.14 & 0.16 & 0.38 & 1.22 \\
\hline & LT & 0.37 & 0.21 & 0.16 & 0.17 & 0.40 & 1.30 \\
\hline & $\mathrm{ST}$ & 0.36 & 0.20 & 0.15 & 0.17 & 0.41 & 1.29 \\
\hline & Significance & n.s. & n.s. & n.s. & n.s. & n.s. & n.s. \\
\hline \multirow{4}{*}{2010} & CK & 0.51 & $0.26 \mathrm{a}$ & 0.28 & 0.29 & 0.71 & $2.04 \mathrm{a}$ \\
\hline & $\mathrm{LT}$ & 0.43 & $0.22 \mathrm{~b}$ & 0.23 & 0.25 & 0.59 & $1.71 \mathrm{~b}$ \\
\hline & $\mathrm{ST}$ & 0.51 & $0.25 \mathrm{ab}$ & 0.28 & 0.30 & 0.63 & $1.95 \mathrm{ab}$ \\
\hline & Significance & n.s. & $*$ & n.s. & n.s. & n.s. & $*$ \\
\hline \multirow{4}{*}{2011} & $\mathrm{CK}$ & 0.17 & 0.11 & 0.07 & 0.08 & 0.17 & 0.59 \\
\hline & LT & 0.16 & 0.10 & 0.07 & 0.08 & 0.16 & 0.56 \\
\hline & $\mathrm{ST}$ & 0.16 & 0.10 & 0.07 & 0.08 & 0.16 & 0.57 \\
\hline & Significance & n.s. & n.s. & n.s. & n.s. & n.s. & n.s. \\
\hline
\end{tabular}

*Significant at $p<0.05$; ns, not significant. Means within a column followed by different letters are significantly different according to the Student- Newman-Keuls test. CK, control vines; LT, lightly trimmed vines; ST, severely trimmed vines. 